Arq. Bras. Med. Vet. Zootec., v.67, n.6, p.1669-1674, 2015

\title{
Behaviour of cockatiels (Nymphicus hollandicus) at two temperatures in captivity
}

\author{
[Comportamento de calopsita (Nymphicus hollandicus) sob duas temperaturas em cativeiro] \\ T.S.G. Carvalho ${ }^{1}$, M.G. Zangeronimo ${ }^{1}$, C.E.P. Saad ${ }^{1}$, R.R. Alvarenga ${ }^{1}$, V.D.L. Assis ${ }^{2}$, \\ V.M. Pereira ${ }^{3}$, J.D. Scalon ${ }^{1}$, J.P. Silva \\ ${ }^{1}$ Universidade Federal de Lavras - Lavras, MG \\ ${ }^{2}$ Universidade Federal de Goiás - Goiânia, GO \\ ${ }^{3}$ Universidade Federal de Minas Gerais - Belo Horizonte, MG
}

\begin{abstract}
Behavioural studies with cockatiels (Nymphicus hollandicus) in captivity are scarce. Due to the need for appropriate management of these animals, this study was performed to examine the behaviour of cockatiels kept in captivity at two temperatures. Sixteen cockatiels were individually housed in cages $(62 \mathrm{~cm}$ high $\times 43 \mathrm{~cm}$ long $\mathrm{x} 27 \mathrm{~cm}$ wide) and fed with a commercial ration and seed mixture for psittacids. Water was provided ad libitum. The eight-day experiment was divided into two stages of four days each. In the first stage, the birds were kept at room temperature $\left(25^{\circ} \mathrm{C}\right)$ with $70 \%$ relative humidity during 24 hours. In the next stage, they were kept at $35^{\circ} \mathrm{C}$ from $06: 00$ to $18: 00 \mathrm{~h}$ and $25^{\circ} \mathrm{C}$ from 18:00 to $06: 00 \mathrm{~h}$, also at $70 \%$ relative humidity. The behaviour of the birds was assessed by the analysis of video recordings taken from 6:00 to 18:00h. Lateral displacement on the perch, walking on the wire net, resting on the abdomen, stopping on the wire net, standing on the drinker or feeder, seed intake, cleaning the wings and shaking the plumage were not influenced $(\mathrm{P}>0.08)$ by temperature. Undesirable activities such as gnawing the perch or the wire net also showed no influence of temperature $(\mathrm{P}>0.15)$. At $35^{\circ} \mathrm{C}$, the birds remained on the cage floor less often $(\mathrm{P}<0.02)$ and more often on the perch. Flapping or gnawing the feeder increased as did the consumption of ration $(\mathrm{P}<0.01)$. Increase in temperature from 25 to $35^{\circ} \mathrm{C}$ changed the behaviour of the cockatiels, although these behaviours were not characterised as responses to temperature stress.
\end{abstract}

Keywords: birds, Psittaciformes, parrot, thermal comfort, captivity, animal welfare

\section{RESUMO}

Estudos comportamentais com calopsitas (Nymphicus hollandicus) em cativeiro são escassos. Devido à necessidade de um manejo adequado desses animais, este estudo foi realizado para avaliar o comportamento de calopsitas mantidas em cativeiro em duas temperaturas. Dezesseis calopsitas foram alojadas individualmente em gaiolas $(62 \mathrm{~cm}$ de altura $\times 43 \mathrm{~cm}$ de comprimento $\times 27 \mathrm{~cm}$ de largura) $e$ alimentadas com ração comercial e mistura de sementes para psitacídeos. A água foi fornecida ad libitum. O período experimental foi de oito dias, dividido em duas fases de quatro dias cada. Na primeira fase, as aves foram mantidas à temperatura ambiente $\left(25^{\circ} \mathrm{C}\right)$, com $70 \%$ de umidade relativa, durante $\mathrm{o}$ dia e a noite. Na etapa seguinte, elas foram mantidas a $35^{\circ} \mathrm{C}$ de $6-18 \mathrm{~h}$ e $25^{\circ} \mathrm{C}$ de $18-6 h$, também com $70 \%$ de umidade relativa. O comportamento das aves foi avaliado através de filmagem de 6-18h. Os comportamentos, deslocando lateralmente no poleiro, andando na tela da gaiola, repousando sobre o ventre, paradas na tela da gaiola, de pé sobre o bebedouro ou comedouro, ingestão de sementes, limpeza das asas e sacudindo a plumagem, não foram influenciados $(P>0,08)$ pelas duas temperaturas testadas. Atividades indesejáveis, tais como roer o poleiro ou a tela da gaiola também não foram influenciadas $(P>0,15)$. Sob a temperatura de $35^{\circ} \mathrm{C}$, as aves permaneceram menos frequentemente no chão da gaiola $(P<0,02)$ e mais frequentemente no poleiro. Nessa temperatura, bater as asas e roer o comedouro

Recebido em 7 de agosto de 2014

Aceito em 7 de julho de 2015

*Autor para correspondência (corresponding author)

E-mail: saadzoo@dzo.ufla.br 
aumentaram com o aumento do consumo de ração $(P<0,01)$. Concluiu-se que o aumento da temperatura de 25 para $35^{\circ} \mathrm{C}$ alterou o comportamento das calopsitas, embora esses comportamentos não pudessem ser caracterizados como respostas ao estresse térmico.

Palavras-chave: aves, Psittaciformes, psitacídeo, conforto térmico, cativeiro, bem-estar animal

\section{INTRODUCTION}

The cockatiel (Nymphicus hollandicus) is an Australian bird belonging to the order Psittaciformes, family Psittacidae, subfamily Cacatuinae (BirdLife International 2012). The smallest species of existing cockatoo, measuring approximately 30-32 cm long (Forshaw, 2010; Gorman, 2010) and almost universally regarded as the most docile of all parrots, cockatiels can be found in open woodlands, farmlands, urban parks and gardens. They are extremely attractive and showy and can live up to 20 years or more (Gorman, 2010). Because of this, the maintenance of psittacids in captivity has increased in some countries and is regulated by local official organisations.

The environment in which the birds are kept is considered an important aspect of their survival. Factors such as temperature, humidity and air movement, which represent the thermal conditions of the environment, can directly influence the behaviour of the birds. Studies have shown that the optimal conditions for maintenance in the wild differ from those kept in captivity. Environmental temperature, for example, plays an important role. Exposure to high ambient temperature causes physiological dysfunction (Mujahid et al., 2007) due to the secretion of corticosteroids, which severely depresses the animal's health due to their catabolic nature. In most cases, confinement provides little space for the behavioural adjustments necessary to maintain thermal homeostasis. Because of this, captivity can represent a limiting factor that leads many animals to express different behaviours, most of which are considered undesirable, such as routetracing and self-plucking (Meehan et al., 2003). These behaviours are sometimes neurotic (stereotyped) and considered abnormal because captivity does not provide the same conditions as the natural habitat (Meehan et al., 2004). When the environmental temperature rises above the thermal comfort zone, the birds experience thermal stress. In most regions of the planet, the temperature during the day is higher than that during the night. In some countries, such as Brazil, the temperature during the day can sometimes surpass the thermal comfort zone of some species of animals. In Australia, the maximum average summer temperature is $33^{\circ} \mathrm{C}$, while during the winter, the minimum average temperature is $9{ }^{\circ} \mathrm{C}$ (Quensland Government, 2004).

Little information was found in the literature about the influence of temperature on the behaviour of captive cockatiels. Understanding the activities of wild birds in captivity is important for the ideal management of these animals and for reducing at least the main stressful factors. Thus, the aim of this study was to evaluate the behaviour of captivity cockatiels (Nymphicus hollandicus) kept in a thermal comfort and in a heat temperature.

\section{APPROACH}

The survey was conducted from April-May 2013 in the climatic chamber of the Department of Animal Science, Federal University of Lavras (UFLA), which is located in Lavras, Minas Gerais, Brazil. The experimental protocol was approved by the Ethics Committee on Animal Use (CEUA) of the same institution under the number 029/13.

The climatic chamber was equipped with an automated system (MT-530 Super, Full Gauge Controls, Canoas-RS, Brazil) that controlled the circulation of heated or cooled air in the room using infrared lamps, blowers and fans. All the equipment was connected to a central panel, allowing the automatic adjustment of the internal temperature of the chamber. In the high temperature environment, the control panel was set to $35{ }^{\circ} \mathrm{C}$, while in the lower temperature environment, it was set at $25^{\circ} \mathrm{C}$. The relative humidity was set to $70 \%$ at both temperatures. The air in the chamber was changed constantly and was regulated by blowers and fans attached to a pipe with small holes for air distribution. The system automatically stayed on for 15 minutes and off for two minutes. The 
temperature was monitored daily inside the rooms at 8:00, 13:00 and 18:00 $\mathrm{h}$ using maximum and minimum thermometers placed at half the height of the animals. The lighting program used was 24 hours of artificial light with infrared light 250w (Ecolume, Belo Horizonte, Brazil).

Sixteen cockatiels ( $N$. hollandicus) (eight males and eight females) born in a commercial hatchery that were approximately one year old were housed individually in cages $(62 \mathrm{~cm}$ high $\mathrm{x}$ $43 \mathrm{~cm}$ long $x 27 \mathrm{~cm}$ wide) made of galvanised wire and adapted with two plastic feeders each, one for ration and another for seed mixture. Individual round ceramic drinkers $(10 \mathrm{~cm}$ diameter) were used to provide water. The distance between the cages was $40 \mathrm{~cm}$.

The animals were fed a commercial ration for psittacids (Complete Food for Parrots, CC Bio Tron, Rio Claro, São Paulo, Brazil) and a seed mixture $(50 \%$ millet, $30 \%$ canary seed, $15 \%$ oats and $5.0 \%$ sunflower) commonly used in some commercial hatcheries in Brazil (Torloni, 1991). Water was supplied ad libitum.

The birds were subjected to a period of acclimation to the experimental conditions for one week. The experimental time was eight days, divided into two stages of four days each. In the first stage (T25), the birds were maintained at an ambient temperature of $25^{\circ} \mathrm{C}$ and $70 \%$ relative humidity during the day and night. In the next stage (T35), the birds were maintained at an ambient temperature of $35^{\circ} \mathrm{C}$ from $06: 00$ to $18: 00 \mathrm{~h}$ and $25^{\circ} \mathrm{C}$ from $18: 00$ to $06: 00 \mathrm{~h}$, also at $70 \%$ relative humidity. The seeds and ration provided and the waste produced were measured daily.

The behaviour of the birds was assessed in the last day of each period by filming from 6:00 to $18: 00$ h with a camcorder $(8.0 \mathrm{~mm}$ CCD Colour
Camera 1/3 Infrared ST1230, Campina Grande do Sul, Paraná, Brazil). The images of each bird were analysed by the same evaluator. Every ten minutes, the activities of the animals were recorded following the focal sampling technique adapted from Altmann (1974) in a pre-defined ethogram (Fig. 1) based on the observations of Prestes (2000), who evaluated the spectacled parrot (Amazona pretrei) of the order Psittaciformes also in captivity. The focal sampling technique consisted of registering the type of activity performed by the animal at a specific time. All birds were observed at the same time during the analysis of the videos. Using the total number of behaviours registered for each animal, the percentage of each behaviour was calculated for each bird.

The body temperature was always measured at 18:00h using the FLIR E50 device (Nashua, USA). The feed and seed intake was determined based on the difference between the amount provided and the waste.

The data were analysed using the statistical program $\mathrm{R}$ ( $\mathrm{R}$ Development Core Team) to compare the evaluated parameters between the two periods (T25 and T35). Each bird was considered an experimental unit. The normal distribution of the data was evaluated by the Shapiro-Wilk test. Then, Student's t-test for paired data was used. For behaviours that only occurred a few times and therefore did not achieve a normal distribution $(\mathrm{P}<0.05)$, double contingency tables were constructed, in which the behavioural variables served as row categories (presence or absence) and the temperature conditions served as column categories (T25 or T35). From these tables, the null hypothesis (i.e., the hypothesis that the behaviour was independent of temperature) was tested using Pearson's chi-squared test of independence. In all cases, $\alpha$ was taken as 0.05 . 


\begin{tabular}{|c|c|c|c|c|c|c|c|c|c|c|c|c|c|c|}
\hline \multicolumn{15}{|c|}{$\begin{array}{l}\text { Species: } \\
\text { Ethogram: MP-moving laterally on the perch; WS-walking on the screen cage; FW-flapping the wings; } \\
\text { SB-standing on the belly; SP-standing on the perch; SS-stopping on the screen; SF-stopping on the cage } \\
\text { floor; CF-clearing feathers with its beak; WP-wagging its plumage; UD-perching upon the drinker or } \\
\text { drinking water; UF-perching upon the feeder or eating; BR-biting the roost; BP-biting the pot supply; } \\
\text { BS-biting the screen cage. }\end{array}$} \\
\hline & \multicolumn{14}{|c|}{ Behavioural categories } \\
\hline & \multicolumn{3}{|c|}{ Locomotion } & \multicolumn{4}{|c|}{ Rest } & \multicolumn{2}{|c|}{$\begin{array}{c}\text { Maintenanc } \\
\mathrm{e}\end{array}$} & \multicolumn{2}{|c|}{ Feeding } & \multicolumn{3}{|c|}{$\begin{array}{c}\text { Undesirable } \\
\text { activities }\end{array}$} \\
\hline Time & MP & $\begin{array}{c}\text { WW } \\
\mathrm{N}\end{array}$ & \begin{tabular}{|c|}
$\mathrm{F}$ \\
$\mathrm{W}$ \\
\end{tabular} & SA & SP & $\begin{array}{c}\text { SW } \\
\mathrm{N}\end{array}$ & SF & $\mathrm{CF}$ & WP & $\begin{array}{l}\mathrm{U} \\
\mathrm{D}\end{array}$ & UF & BR & $\mathrm{BP}$ & $\mathrm{BS}$ \\
\hline 10 & & & & & & & & & & & & & & \\
\hline 20 & & & & & & & & & & & & & & \\
\hline 30 & & & & & & & & & & & & & & \\
\hline 40 & & & & & & & & & & & & & & \\
\hline 50 & & & & & & & & & & & & & & \\
\hline 60 & & & & & & & & & & & & & & \\
\hline $\begin{array}{l}\text { MP-Mov } \\
\text { WWN-Y } \\
\text { FW-Flap } \\
\text { SA-Stan } \\
\text { the chest } \\
\text { SP-Stanc } \\
\text { are not rn } \\
\text { SWN-St } \\
\text { SF-Stopr } \\
\text { CF-Clea } \\
\text { the tip or } \\
\text { WP-Wag } \\
\text { accomm } \\
\text { UD-Perc } \\
\text { the pot's } \\
\text { UF-Perc } \\
\text { BP-Bitin } \\
\text { BD-Bitin } \\
\text { BS-Bitin }\end{array}$ & $\begin{array}{l}\text { ing wi } \\
\text { ing on } \\
\text { ng on t } \\
\text { fled, a } \\
\text { pping } \\
\text { ng on } \\
\text { ng feat } \\
\text { eear th } \\
\text { ing its } \\
\text { dating } \\
\text { ing up } \\
\text { inzzle. } \\
\text { ing upc } \\
\text { the pe } \\
\text { the dr } \\
\text { the sc }\end{array}$ & $\begin{array}{l}\text { s: the b } \\
\text { e abdor } \\
\text { perch } \\
\text { the ne } \\
\text { the wir } \\
\text { floor } \\
\text { ers with } \\
\text { belly, w } \\
\text { lumage } \\
\text { athers } \\
\text { the dri } \\
\text { on the } \\
\text { h: the } \\
\text { ker of } \\
\text { en cage }\end{array}$ & $\begin{array}{l}\text { : when } \\
\text { ck is } \\
\text { re net: } \\
\text { of fla } \\
\text { of the } \\
\text { its be } \\
\text { ith its } \\
: \text { the b } \\
\text { ffter ty } \\
\text { inker } \\
\text { feede } \\
\text { jird tri } \\
\text { feeder } \\
: \text { the }\end{array}$ & $\begin{array}{l}\text { ps its } \\
\text { ne bird } \\
\text { on th } \\
\text { n a no } \\
\text { the bi } \\
\text { cage: } \\
\text { ak: th } \\
\text { head } \\
\text { ird's f } \\
\text { vo or } t \\
\text { r at dr } \\
\text { or eat } \\
\text { es to d } \\
\text { The } \\
\text { ird tri }\end{array}$ & $\begin{array}{l}\text { vings } \\
\text { rests, } \\
\text { perch } \\
\text { mal p } \\
\text { d rem } \\
\text { he birc } \\
\text { bird } \\
\text { oward } \\
\text { athers } \\
\text { rree jo } \\
\text { nking } \\
\text { ing: th } \\
\text { estroy } \\
\text { ird trie } \\
\text { s to d }\end{array}$ & $\begin{array}{l}\text { n a ne } \\
\text { ition. } \\
\text { ss on } t \\
\text { s stan } \\
\text { es its } \\
\text { ne bac } \\
\text { ristle } \\
\text { throu } \\
\text { ater: } t \\
\text { bird re } \\
\text { er roo } \\
\text { to des } \\
\text { troy th }\end{array}$ & $\begin{array}{l}\text { ig on } \\
\text { ak to } c \\
\text { The b } \\
\text { the b } \\
\text { nout tl } \\
\text { bird }\end{array}$ & $\begin{array}{l}\text { hout sh } \\
\text { legs be } \\
\text { ture, th } \\
\text { of the } \\
\text { he cage } \\
\text { ean its } \\
\text { rd bend } \\
\text { dy, esp } \\
\text { e body. } \\
\text { erches } \\
\text { n the fe } \\
\text { biting } \\
\text { feeder } \\
\text { cage by }\end{array}$ & $\begin{array}{l}\text { king its } \\
\text { t, its w } \\
\text { bird ke } \\
\text { age, sh } \\
\text { loor, sh } \\
\text { athers. } \\
\text { its bod } \\
\text { cially th } \\
\text { n the d } \\
\text { der, sto } \\
\text { twith i } \\
\text { g gnawi }\end{array}$ & $\begin{array}{l}\text { owin } \\
\text { This } \\
\text { y corr } \\
\text { le nec } \\
\text { inker }\end{array}$ & $\begin{array}{l}\text { legs } \mathrm{s} \\
\text { no } \mathrm{m} \\
\text { no } \mathrm{m} \\
\text { act car } \\
\text { espon } \\
\mathrm{k} \text {, che } \\
\text { of wat } \\
\text { or eati }\end{array}$ & $\begin{array}{l}\text { elly, ar } \\
\text { ightly } \\
\text { vemer } \\
\text { veme } \\
\text { be per } \\
\text { ing to } \\
\text {, and } \\
\text { ror or } \\
\text { ig. } \\
\text { beak. }\end{array}$ & $\begin{array}{l}\text { its cla } \\
\text { art. Th } \\
\text { rmed } \\
\text { e wing } \\
\text { ck, } \\
\text { ks wa }\end{array}$ & $\begin{array}{l}\text { under } \\
\text { eathers } \\
\text { er at } \\
\text { from }\end{array}$ \\
\hline
\end{tabular}

Figure 1. Ethogram for evaluating the behavioural parameters of individual cockatiels (Nymphicus hollandicus).

\section{RESULTS AND DISCUSSION}

The birds maintained at T35 displayed higher body surface temperature $(\mathrm{P}<0.01)$ compared to those maintained at T25. Most of the cockatiels' activities did not appear to be affected $(\mathrm{P}>0.08)$ by the ambient temperature, including lateral displacement on the perch, walking on the cage wire net, resting on the abdomen, stopping on the wire net, standing on the drinker or feeder, seed intake, clearing the wings and shaking the plumage (Table 1). Undesirable activities, such as gnawing the roost or the screen cage also did not appear to be influenced $(\mathrm{P}>0.15)$. At $35^{\circ} \mathrm{C}$, the birds remained less often on the cage floor $(\mathrm{P}$ $=0.02)$ and more often on the perch $(\mathrm{P}=0.05)$. 
An increased consumption of ration was observed $(\mathrm{P}<0.01)$ at this temperature. Activities such as flapping or gnawing the feeder were detected at T35.

Behavioural studies in cockatiels of the species $N$. hollandicus kept in captivity are scarce. The choice of temperatures used in this experiment was based on the fact that the range of thermal comfort for cockatiels lies between 18.0 and $23.8^{\circ} \mathrm{C}$, and the temperatures of thermal discomfort are considered to be below $12.7^{\circ} \mathrm{C}$ or above $32.2{ }^{\circ} \mathrm{C}$ (Gorman, 2010). In the second period of this study (T35), the birds were subjected to a temperature of $35^{\circ} \mathrm{C}$ from $06: 00$ to 18:00 $\mathrm{h}$ to simulate the natural environment of cockatiels (i.e., higher temperatures during the daytime and lower temperatures at night).

Table 1. Behavioural, feed intake, body surface temperature, and seed consumption variables for cockatiels kept at two ambient temperatures during the day $(\mathrm{n}=16)$

\begin{tabular}{|c|c|c|c|c|c|}
\hline \multirow[t]{2}{*}{ Variable } & \multicolumn{2}{|c|}{$\begin{array}{l}\text { Ambient temperature during the day } \\
\text { (mean } \pm \text { standard deviation) }\end{array}$} & \multirow{2}{*}{$\begin{array}{l}\text { Degree of } \\
- \text { freedom }\end{array}$} & \multirow{2}{*}{$\begin{array}{l}\mathrm{t}(*) \text { or } \\
\chi^{2}(* *) \\
\text { value }\end{array}$} & \multirow[t]{2}{*}{ P-value } \\
\hline & $25^{\circ} \mathrm{C}$ & $35^{\circ} \mathrm{C}$ & & & \\
\hline \multicolumn{6}{|l|}{ Temperature of the bird $\left({ }^{\circ} \mathrm{C}\right)$} \\
\hline Maximum & $30.80 \pm 0.80$ & $31.61 \pm 0.91$ & 15 & $4.16^{*}$ & $<0.01$ \\
\hline Average & $25.72 \pm 0.71$ & $27.44 \pm 0.63$ & 15 & $18.5^{*}$ & $<0.01$ \\
\hline Minimum & $23.45 \pm 0.57$ & $25.18 \pm 0.43$ & 15 & $17.3 *$ & $<0.01$ \\
\hline \multicolumn{6}{|l|}{ Locomotion $(\%)$} \\
\hline Lateral displacement on the perch & $0.13 \pm 0.50$ & $0.31 \pm 0.60$ & 15 & $0.36 * *$ & 0.55 \\
\hline Walking on the screen cage & $2.81 \pm 3.66$ & $2.19 \pm 1.56$ & 15 & $0.76^{*}$ & 0.46 \\
\hline Flapping its wings successively & $0.00 \pm 0.00$ & $0.06 \pm 0.25$ & - & - & - \\
\hline \multicolumn{6}{|l|}{ Rest $(\%)$} \\
\hline Resting on the abdomen & $0.13 \pm 0.50$ & $0.13 \pm 0.34$ & 15 & $0.01 * *$ & 0.99 \\
\hline Standing on the perch & $15.62 \pm 15.02$ & $21.81 \pm 15.82$ & 15 & $2.03^{*}$ & 0.05 \\
\hline Stopped on the screen & $2.19 \pm 1.56$ & $2.43 \pm 4.31$ & 15 & $0.65^{*}$ & 0.52 \\
\hline Standing on the floor of the cage & $22.75 \pm 14.31$ & $16.94 \pm 12.89$ & 15 & $2.55^{*}$ & 0.02 \\
\hline \multicolumn{6}{|l|}{ Maintenance $(\%)$} \\
\hline $\begin{array}{l}\text { Clearing the wings with the tip of } \\
\text { the beak }\end{array}$ & $3.06 \pm 2.21$ & $4.31 \pm 2.02$ & 15 & $1.45^{*}$ & 0.17 \\
\hline Shaking its plumage & $0.38 \pm 0.62$ & $0.13 \pm 0.34$ & 15 & $0.04 * *$ & 0.84 \\
\hline \multicolumn{6}{|l|}{ Feeding $(\%)$} \\
\hline Standing on the drinker & $6.06 \pm 10.64$ & $4.06 \pm 7.00$ & 15 & $1.06^{*}$ & 0.31 \\
\hline Standing on the feeder & $12.81 \pm 12.7$ & $12.25 \pm 9.78$ & 15 & $0.20 *$ & 0.84 \\
\hline \multicolumn{6}{|l|}{ Undesirable activities (\%) } \\
\hline Gnawing the perch & $0.06 \pm 0.25$ & $0.13 \pm 0.34$ & 15 & $0.01 * *$ & 0.99 \\
\hline Gnawing the feeder & $0.00 \pm 0.00$ & $0.06 \pm 0.25$ & - & - & - \\
\hline Gnawing the screen cage & $3.00 \pm 3.71$ & $4.19 \pm 3.45$ & 15 & $1.50^{*}$ & 0.15 \\
\hline Ration consumption (g/bird/day) & $2.47 \pm 1.20$ & $2.85 \pm 1.33$ & 15 & $3.12 *$ & $<0.01$ \\
\hline Seed consumption (g/bird/day) & $11.20 \pm 1.99$ & $11.91 \pm 2.16$ & 15 & $1.91 *$ & 0.08 \\
\hline
\end{tabular}

The environmental conditions studied significantly interfered with few of the behaviours exhibited by the birds. Compared to $25^{\circ} \mathrm{C}$, the high temperature caused the birds to remain more often on the perch instead of on the floor of the cage. This can be explained by the fact that the animals prefer well-ventilated areas, facilitating body heat dissipation (Kenny and Jay, 2013). Behavioural adjustments can occur quickly and at a lower cost than physiological adaptations. Thus, the behaviour of animals represents a direct tool that a wild bird has to defend itself from dangers in the surrounding environment. Parrot species that are kept as pets often exhibit behavioural problems, such as escape attempts, panic, and aggression, that are considered typical in captive environments (Meehan et al., 2004). In the present study, behaviours that indicate physiological stress were not observed, suggesting that the temperature was not high enough to damage the health of the birds. 
The surface body temperature of the cockatiels increased when the ambient temperature was increased from 25 to $35^{\circ} \mathrm{C}$. Increased skin temperature is a result of a high ambient temperature or increased blood flow at the body surface (Simeone et al., 2004). Previous studies indicate that birds have the ability to adapt morphologically, physiologically, and behaviourally to achieve thermal homeostasis, but factors such as feather coverage, sex, age, and degree of acclimatisation can interact with relative humidity to define responses to high ambient temperatures (Balnave, 2004). In the present study, behavioural changes, such as remaining on the perch, were more important in maintaining thermal homeostasis.

The ingestion of ration increased when the temperature increased from 25 to $35^{\circ} \mathrm{C}$. This result may be related to the increase in the behaviour "gnawing the feeder" when the higher temperature was applied. The proximity of the bird to the ration may have stimulated the ingestion of feed.

In general, cockatiels are psittacines from the desert regions of Australia (Forshaw, 2010). Despite domestication over the years, they are genetically adapted to elevated temperatures. Because of this, no behaviour that suggested stress was observed in the present study.

\section{CONCLUSION}

The increase in temperature from 25 to $35^{\circ} \mathrm{C}$ changed the behaviour of the cockatiels, increasing permanence on the perch, flapping and gnawing the feeder; however, due to the higher feed intake, these behaviours were not indicative of thermal stress, condition which would result in reduced feed intake.

\section{ACKNOWLEDGEMENTS}

We would like to thank the Coordenação de Aperfeiçoamento de Pessoal de Nível Superior (CAPES) and the Fundação de Amparo a Pesquisa do Estado de Minas Gerais (FAPEMIG - Programa Pesquisador Mineiro - PPM 0046012) for financial support.

\section{REFERENCES}

ALTMANN, J. Observational study of behaviour: sampling methods. Behaviour. v.49, p.227-267,1974.

ANNUAL temperature study report. Data Analysis Report. 2004. Available in: $<$ http://www.hpw.qld.gov.au/SiteCollectionDocuments/ TemperatureStudyAnnualReport2002-03.pdf> Accessed Jun. 2015.

BALNAVE, D. Challenges of accurately defining the nutrient requirements of heat-stressed poultry. Poultry Sci. v.83, p.5-14, 2004.

BIRDLIFE INTERNATIONAL. 2012. Nymphicus hollandicus. In: IUCN red list of threatened species. Version 2013.1. Available in: $<$ http://www.iucnredlist.org. $>$. Accessed: Aug. 2013.

FORSHAW, J.M. Parrots of the world. Princeton: Princeton University Press, 2010.

GORMAN, M. The cockatiel handbook. New York: [s.n.], 2010. (Barron's educational series)

KENNY, G.P.; JAY, O. Thermometry, calorimetry, and mean body temperature during heat stress. Compr. Physiol., v.3, p.1689-1719, 2013.

MEEHAN, C.L.; GARNER, J.P.; MENCH, J.A. Isosexual pair housing improves the welfare of young Amazon parrots. Appl. Anim. Behav. Sci., v.81, p.7388, 2003.

MEEHAN, C.L.; GARNER, J.P.; MENCH, J.A. Environmental enrichment and development of cage stereotypy in orange-winged Amazon parrots (Amazona amazonica). Dev. Psychobiol., v.44, p.209$218,2004$.

MUJAHID, A.; AKIBA, Y.; TOYOMIZU, M. Acute heat stress induces oxidative stress and decreases adaptation in young white leghorn cockerels by downregulation of avian uncoupling protein. Poultry Sci., v.86, p.364-371, 2007.

PRESTES, P.N. Description and quantitative analysis of etogram of Amazon petrei in captivity. Ararajuba, v.8, p. $25-42,2000$.

SIMEONE, A.; JORQUERA, G.L.;.WILSON, R.P. Seasonal variations in the behavioural thermoregulation of roosting Humboldt penguins (Spheniscus humboldti) in northern Chile. J. Ornithol. v.145, p.35-40, 2004.

TORLONI, C.E.E. Criação de calopsitas. Guarulhos: LIS Gráfica e Editora LTDA, 1991. 89p. 